\title{
EFFECT OF SALT STRESS ON DECOMPOSITION OF ORGANIC MATTER AND NITROGEN MINERALIZATION IN ANIMAL MANURE AMENDED SOILS
}

\author{
B. C. Walpola ${ }^{1}$ and K. K. I. U. Arunakumara ${ }^{2}$
}

\begin{abstract}
As it is believed that soil salinity can alter the organic matter turnover process, the present study discussed the influence of soil salinity on the decomposition of organic matter and nitrogen mineralization in animal manure amended soils. A factorial combination of two soil types (saline and non-saline soils) with three types of animal manure (i.e. poultry manure, goat manure and cow dung) was used to assess the $C$ and $N$ mineralization.

The amount of $\mathrm{CO}_{2}-\mathrm{C}$ released from both soils was not significant $(P \leq 0.05)$ until day 2 of incubation. However, as incubation progressed, the amount of $\mathrm{CO}_{2}-\mathrm{C}$ released from manure amended soils was found to be significantly $(P \leq 0.05)$ higher than that of the control. However in the case of cow dung amended soils, release of $\mathrm{CO}_{2}-\mathrm{C}$ was not much influenced by the salinity stress. The $\mathrm{NH}_{4}^{+}-\mathrm{N}$ content of both soils was found to be reached to the peak at day 14, followed by gradual reductions in all treatments. However, saline soil showed significantly $(P \leq 0.05)$ low $\mathrm{NH}_{4}{ }^{+}-\mathrm{N}$ content compared to the non-saline soil. Though, the nutritional composition of applied manures was different, no significant $(P \leq 0.05)$ differences were found among the treatments in terms of $N$ mineralization. Furthermore, no distinct pattern of treatment behavior could be observed for $\mathrm{NO}_{3}^{-}-\mathrm{N}$ contents also. However, the content of $\mathrm{NO}_{3}^{-}-\mathrm{N}$ was found to be dominated in non-saline soil throughout the incubation. Results could be concluded that the response pattern of $C$ and $N$ mineralization to salinity stress depended on the type of animal manure incorporate to the soil and duration of incubation.
\end{abstract}

Key words: salinity stress, animal manure, decomposition of organic matter, nitrogen mineralization

\section{INTRODUCTION}

Soil salinization is one of the major factors that contribute to land degradation and decrease in crop yield (Al Yassin, 2005; Anjum et al, 2005). Salt-affected soils are characterized by high concentrations of soluble salts and low organic matter and nitrogen content (Asmalodhi et al, 2009). The negative effects of salinization are intensified by the low levels of soil organic matter (Muhammad et al, 2005) and decreasing stability of soil structure, i.e. the tendency to slake, disperse and swell under specific conditions (Qadir and
Schubert, 2002). In contrast to soil physical and chemical properties, a little attention has been paid on soil microbiological aspects of saline environments. However, recent studies clearly revealed the adverse effects of salinization on the soil microbial biomass (Rietz and Haynes, 2003). In particular, the fungal part of the microbial biomass estimated by PLFA (phospholipid fatty acids) (Pankhurst et al, 2001) or ergosterol analysis (Sardinha et al, 2003) was strongly reduced in saline soils. Salinization has been identified as one of the most stressing environmental

${ }^{I}$ Department of Soil Science, Faculty of Agriculture, University of Ruhuna, Mapalana, Kamburupitiya, Sri Lanka.

${ }^{2}$ Department of Crop Science, Faculty of Agriculture, University of Ruhuna, Mapalana, Kamburupitiya, Sri Lanka. 
conditions for soil microorganisms (Sardinha et al, 2003), thus nutrient mineralization of such soil could also be affected by the high concentrations of soluble salts.

Replacement of ions responsible for the salinity either chemically or by adding organic manure is found to be a viable strategy in ameliorating of salt-affected soils (Garcia, 2000). However, release of inorganic forms of $\mathrm{N}, \mathrm{P}$ and other organically-bound nutrients in soil is functionally associated with carbon mineralization (Mafongoya et al, 2000) and hence, is affected by the salinity stress that inhibits the mineralization of organic materials in soil. This inhibition was further illustrated by Nakhone and Tabatabai (2008) who reported that mineralization of nutrients from an organic amendment depends on abiotic factors also in addition to the biotic factors as reported by Rowell et al. (2001). Though the effects of biochemical composition of organic amendments on their decomposition kinetics have been addressed (Thuriès et al, 2002), the possible changes under saline condition are yet to be elaborated.

Under saline conditions, the role of $\mathrm{N}$ becomes crucial as the biological activity of these soils is poor. However, because of low organic matter level of such soils, conservation of $\mathrm{N}$ through microbial immobilization remains limited. As a result, fertilizer $\mathrm{N}$ economy of salt affected soils may not be comparable to normal agricultural soils (Asmalodhi et al, 2009). A number of organic $\mathrm{N}$-containing materials, such as animal manure, sewage sludge and plant residues are being used as soil amendments and a source of $\mathrm{N}$ for improving the soil quality (Yousif and Abdalla, 2009). This practice helps in improving the $\mathrm{N}$ availability status as such or through enhanced $\mathrm{N}$ mineralization from organic matter. However, the process of $\mathrm{N}$ mineralization is significantly affected by factors such as excessive salts, soil temperature and moisture (Asmalodhi et al, 2009). Despite recent literature brings valuable information on many aspects of $\mathrm{N}$ mineralization, the interaction between the quality of organic material and nitrogen mineralization under saline condition is not well understood (Nourbakhsh and Hossein, 2006). In addition, published literature on the effects of salinity on soil biological processes often showed contradictory results (Vanessa et al, 2004). The present paper comparatively discusses the decomposition pattern of organic matter and nitrogen mineralization of animal manure amended saline and non-saline soils.

\section{MATERIALS AND METHODS}

\section{Soil collection}

Laboratory investigation was conducted at the Department of Soil Science, Faculty of Agriculture, University of Ruhuna, Mapalana, Kamburupitiya, Sri Lanka. The soil used in this study belongs to Red Yellow Podzolic great soil group and is classified as Hapludults according to the USDA soil taxonomy (Mapa et al, 1999). Soil samples were collected randomly from fifteen locations along the coastal belt of the Madiha East GS Division, Matara, Sri Lanka to represent the saline soils. Non-saline soil samples were also collected from the same GS Division, but away from the sea. After removing the surface litter, soil samples were taken from $0-15 \mathrm{~cm}$ depth using an auger and mixed thoroughly to make composite samples. The chemicals used in this study were of analytically grade and used without further purification.

\section{Treatments}

Chemical and physical characteristics of soils were determined prior to the study using standard methods (Table 1). Sub samples of $100 \mathrm{~g}$ of homogeneously mixed air dried soil were placed in glass bottles. The soils in bottles were watered to adjust 
the moisture content to $50 \%$ of the field capacity (dry basis) and kept in dark for two weeks prior to addition of animal manures. The moisture content of the soils was monitored daily in order to make sure the sufficient moisture in the bottles. Animal manure (poultry manure, goat manure and cow dung) was collected from the Faculty farm and air dried for three days. After two-week pre-incubation period, the glass bottles were opened and $235 \mathrm{mg}$ of poultry manure, goat manure and cow dung were mixed separately with the soil. The application rate represented 5 tons per hectare, on the assumption that top $15 \mathrm{~cm}$ of an area of 1 ha contains 2.13
$\mathrm{X} 10^{9} \mathrm{~kg}$ soil (soil bulk density $1.42 \mathrm{~g} \mathrm{~cm}$ ${ }^{3}$ ). Soil samples without being amended by animal manure were used as control. The treated soil samples along with the controls were incubated in the dark at room temperature $\left(25 \pm 1^{\circ} \mathrm{C}\right)$. Constant moisture content of the soil was maintained throughout the incubation period. A Completely Randomized Design (CRD) with four replicates was used and the data generated were subjected to analysis of variance (ANOVA) using SAS software (SAS Institute, 1988). Least significant difference at $\mathrm{P} \leq 0.05$ was used to separate the means.

Table 1: Chemical and physical characteristics of saline and non-saline soil

\begin{tabular}{lccl}
\hline \multicolumn{1}{c}{ Property } & Non-Saline Soil & Saline Soil & Analytical Method \\
\hline Soil texture & $\begin{array}{l}\text { Sand }-84 \% \\
\text { Silt }-12 \%\end{array}$ & Sand $-81 \%$ & Sedimentation and \\
& Clay $-04 \%$ & Silt $-08 \%$ & Decantation method \\
& 1.23 & & \\
Bulk Density \\
$\left(\mathrm{g} / \mathrm{cm}^{3}\right)$
\end{tabular}




\section{Decomposition of organic matter}

Soil samples in gas-tight glass containers along with a vial containing $10 \mathrm{ml}$ of $1 \mathrm{M}$ $\mathrm{NaOH}$ to trap $\mathrm{CO}_{2}$ and a vial of water to maintain humidity were incubated at room temperature $\left(25{ }^{\circ} \mathrm{C}\right)$ in the dark. The $\mathrm{NaOH}$ traps were replaced at 2, 5, 7, 14, 21, 28, 35, $42,49,56$ and 70 days after the treatment. Unreacted alkali in the $\mathrm{NaOH}$ traps was titrated with $0.5 \mathrm{M} \mathrm{HCl}$ to determine $\mathrm{CO}_{2}-\mathrm{C}$ released from the soil (Anderson, 1982).

\section{Nitrogen mineralization}

Nitrogen mineralization was determined in terms of inorganic $\mathrm{N}\left(\mathrm{NH}_{4}{ }^{+}-\mathrm{N}\right.$ and $\left.\mathrm{NO}_{3}{ }^{-}-\mathrm{N}\right)$ concentration of soil extracted at 2, 5, 7, 14, $21,28,35,42,49,56$ and 70 days after incubation. Samples containing $10 \mathrm{~g}$ soil were extracted using $30 \mathrm{ml}$ of $2 \mathrm{M} \mathrm{KCl}$ and the extracts was used to determine $\mathrm{NH}_{4}{ }^{+}-\mathrm{N}$ and $\mathrm{NO}_{3}{ }^{-}-\mathrm{N}$. The $\mathrm{NH}_{4}{ }^{+}-\mathrm{N}$ content was determined following the Berthelot reaction (Searle, 1984) and the $\mathrm{NO}_{3}^{-}-\mathrm{N}$ by sodium salicylate yellow color method (Bremner, 1982).

\section{RESULTS AND DSCUSSION}

Periodic changes in the amount of $\mathrm{CO}_{2}-\mathrm{C}$ released from the animal manure amended saline and non-saline soils are depicted in Fig.01. The amount of $\mathrm{CO}_{2}-\mathrm{C}$ released from animal manure amended soils was found to be increased at an increasing rate as incubation progressed. Furthermore, different animal manures resulted in different rates of $\mathrm{CO}_{2}$ evolution. However, the $\mathrm{C}$ mineralization in saline soil was considerably lesser than that of in nonsaline soil. Though no significant differences $(\mathrm{P} \leq 0.05)$ were found among the cumulative $\mathrm{CO}_{2}-\mathrm{C}$ released from the poultry manure, goat manure and cow dung amended soils under non- saline condition $(E C=0.97 \mathrm{dS} / \mathrm{m})$, the respective figures were $0.80,0.82$ and 0.82 times that of in control. However, under saline condition $(E C=18.2 \mathrm{dS} / \mathrm{m})$, cumulative $\mathrm{CO}_{2}-\mathrm{C}$ released from poultry manure, goat manure and cow dung amended soils were found to be significantly different $(\mathrm{P} \leq$ 0.05 ) and $0.85,0.65$ and 0.52 times respectively that of in control.

Under non-saline conditions, the highest carbon mineralization was observed from poultry manure amended soils which can be attributed to the higher biodegradability of poultry manure induced by higher $\mathrm{N}$ content. Nourbakhsh and Dick (2005) demonstrated that the rate of nutrient mineralization potential of a calcareous soil treated with plant residues heavily depended on the $\mathrm{N}$ content of plant residues. This suggests that the readily decomposable fractions of organic $\mathrm{C}$ in poultry manure are greater than those in goat manure and cow dung. In fact, the chemical composition of these animal manures was varied considerably. Since the $\mathrm{C}$ contents of the animal manure are not widely varied, the wide range of the $\mathrm{C}: \mathrm{N}$ ratios can be attributed to the $\mathrm{N}$ concentrations. The $\mathrm{N}$ concentration in poultry manure was about nearly 2 times that of cow dung.

Though no significant $(\mathrm{P} \leq 0.05)$ variation in the amount of $\mathrm{CO}_{2}-\mathrm{C}$ release from both soils was observed until day 2 of the incubation, as the incubation progressed, the released amount was found to be significantly $(\mathrm{P} \leq 0.05)$ different in both soils. However, in the case of cow dung amended soils, $\mathrm{CO}_{2}-\mathrm{C}$ releasing pattern was found to be not influenced by the salinity stress. 

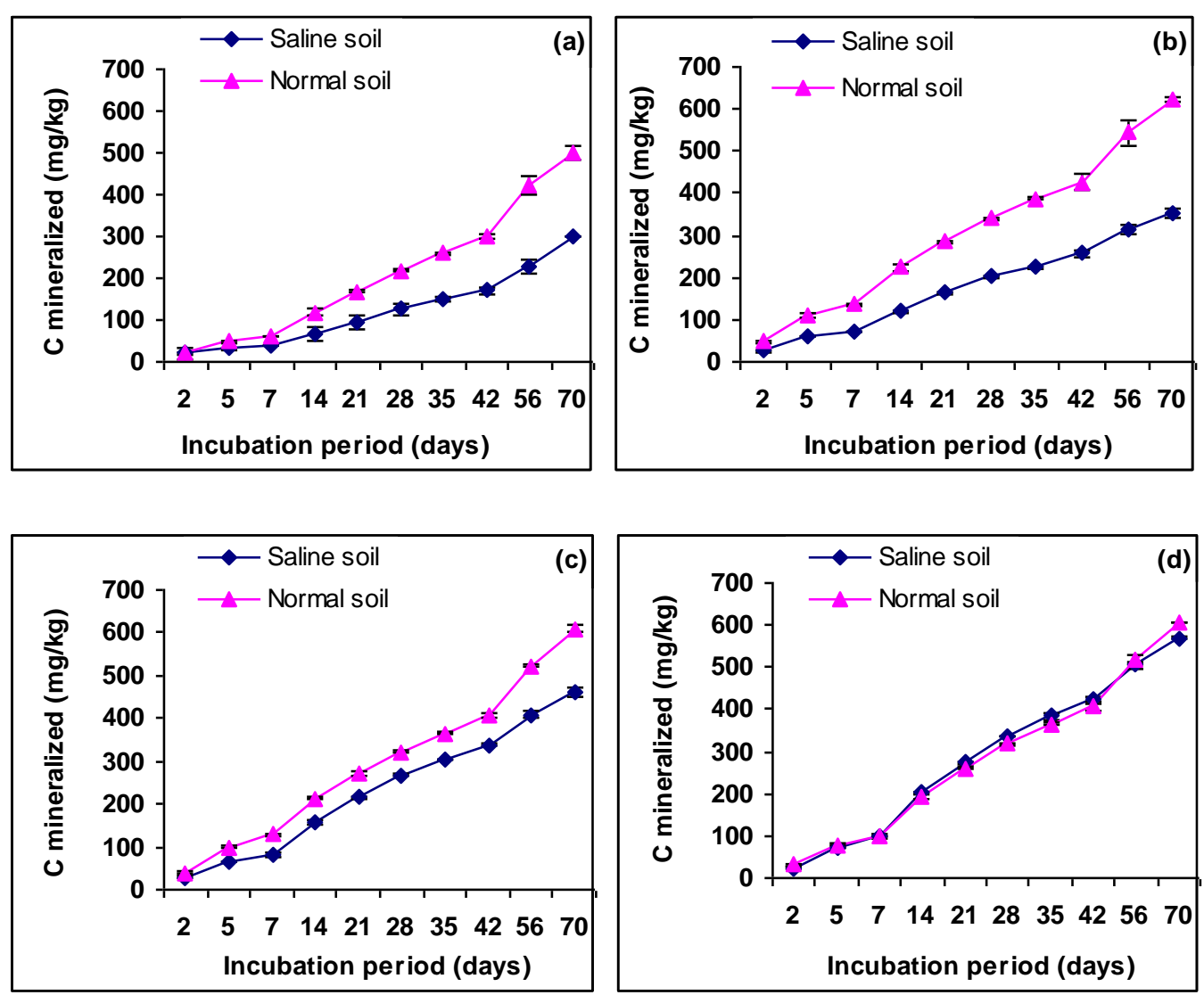

Figure 1: Cumulative $C$ mineralization of the non-saline and saline soil amended with poultry manure (a), goat manure (b), cow dung (c) and untreated control (d). Values given here are the means $(n=4) \pm$ standard deviation.

The salinity caused reductions in the rates of $\mathrm{CO}_{2}$ evolution by 43, 24 and $6 \%$ respectively in poultry manure, goat manure and cow dung amended soils. However, in the case of controls, no marked reduction in the rates of $\mathrm{CO}_{2}$ evolution was observed possibly due to the lower carbon content in saline soils than that of non-saline soil. Sardinha et al. (2003) reported that salinization has stronger effects on microbial properties of soil than heavy-metal pollution, thus it can be considered as one of the most stressing environmental conditions for microbial growth and proliferation in soil. Pathak and Rao (1998) reported that a saline soil
(EC of $16 \mathrm{dS} / \mathrm{m}$ ) decreased the $\mathrm{C}$ mineralization of Sesbania cannabina leaves amended soils. They further reported that addition of organic material, which, in the short term, provides additional substrates for the microbial population, may also relieve osmotic and $\mathrm{pH}$ stress on the microorganisms.

The changes in $\mathrm{NH}_{4}{ }^{+}-\mathrm{N}$ release during the incubation period are shown in Fig. 02. The $\mathrm{NH}_{4}{ }^{+}-\mathrm{N}$ content of both soils was found to be reached to the peak at day 14 followed by gradual reductions in all the treatments. Though, the nutritional composition of applied manures was 
widely varied, no significant $(\mathrm{P} \leq 0.05)$ differences in $\mathrm{N}$ mineralization were found among the treatments. However, saline soil showed significantly $(\mathrm{P} \leq 0.05)$ low $\mathrm{NH}_{4}{ }^{+}$ -N content compared to the non-saline soil. As expected, the control soil recorded a low level of $\mathrm{NH}_{4}{ }^{+}-\mathrm{N}(2-13 \mathrm{mg} / \mathrm{kg}$ soil $)$ compared to that of in manure amended soils. The changes in $\mathrm{NO}_{3}^{-}-\mathrm{N}$ release during incubation period are shown in Fig. 03. Despite no distinct pattern of treatment behavior could be observed for $\mathrm{NO}_{3}{ }^{-}-\mathrm{N}$, non-saline soil showed to have higher $\mathrm{NO}_{3}{ }^{-}-\mathrm{N}$ level throughout the incubation.

The fluctuations of $\mathrm{NH}_{4}{ }^{+}-\mathrm{N}$ release during the incubation suggest that a possible loss of $\mathrm{NH}_{4}{ }^{+}-\mathrm{N}$ from the amended manure by means of $\mathrm{NH}_{3}$ volatilization. The decline in soil $\mathrm{NH}_{4}{ }^{+}-\mathrm{N}$ between 5-7 days of incubation can be explained by an event of rapid nitrification combined with denitrification. The amount of soil $\mathrm{NO}_{3}{ }^{-}-\mathrm{N}$ did not increase between 1-10 days of the incubation suggesting that the $\mathrm{NO}_{3}{ }^{-}-\mathrm{N}$ was taken up by the denitrifiers. As reported by Calderon et al. (2004), this could prevent the increase in the standing $\mathrm{NO}_{3}{ }^{-}-\mathrm{N}$ pool, due to restricted aeration, which encourages denitrification. In fact, this close coupling between nitrification and denitrification which results in a high proportion of the mineralized $\mathrm{N}$ to be lost as $\mathrm{N}$ gas has repeatedly been observed (Nielsen and Revsbech, 1998; Meyer et al, 2002).

In the present study, $\mathrm{NO}_{3}-\mathrm{N}$ was found to be the dominant form of inorganic $\mathrm{N}$, which is not in agreement with Maithani et al. (1998) and Calderon et al. (2004), who observed $\mathrm{NH}_{4}-\mathrm{N}$ as the dominant form of inorganic $\mathrm{N}$. This could be due to slightly alkaline nature $(\mathrm{pH}>7.0)$ of the soil used in the present study, which may have enhanced the growth and the activity of autotrophic nitrifiers in the soils as reported by Chao et al. (1993). Okura (2002) reported that, $\mathrm{N}$ mineralization was more sensitive to salinity than $\mathrm{C}$ mineralization. According to his findings, slightly saline irrigation water (EC of 6.5 $\mathrm{dS} \mathrm{m}^{-1}$ ), caused $47 \%$ reduction in $\mathrm{N}$ mineralization, while in the case of $\mathrm{C}$ mineralization, the same treatment lead to an inhibition of only $17.5 \%$. Sarig et al. (1993) reported that irrigation with saline water $\left(\mathrm{EC}=5 \mathrm{dS} \mathrm{m}^{-1}\right)$ could increase the accumulation of $\mathrm{C}$ and $\mathrm{N}$ in microbial biomass, but decrease the rate of $\mathrm{C}$ and $\mathrm{N}$ mineralization. Rapid ammonification with presumed immobilization occurred up to day 14 and thereafter, $\mathrm{NH}_{4}{ }^{+}$oxidation took place with poultry manure exhibiting the greatest nitrification. Therefore, depression of ammonification and nitrification and the overall decrease in net $\mathrm{N}$ mineralization with increasing $\mathrm{pH}$ or salinity were all evidence of the biological nature of $\mathrm{N}$ mineralization in salt-affected soils.

According to Eneji et al. (2002), laboratory incubations of manured soil lasting for weeks may result in negative $\mathrm{N}$ mineralization values, though Hadas and Portnoy (1994) reported that longer incubations could positively influence $\mathrm{N}$ mineralization. These variations are likely to be due to the differences in soils, materials, $\mathrm{C} / \mathrm{N}$ ratios, application rates and environmental conditions used for the different studies (Yousif and Abdalla, 2009). However, it is well understood that waiting for more than 10 weeks for positive $\mathrm{N}$ mineralization would miss the period of high $\mathrm{N}$ demand of most crops if the soils are planted soon after manuring the field (Calderon et al, 2004). As the present investigation was performed under laboratory conditions, results should be confirmed by the studies conducted under field conditions also because salinity may interact differently with different environmental factors. 

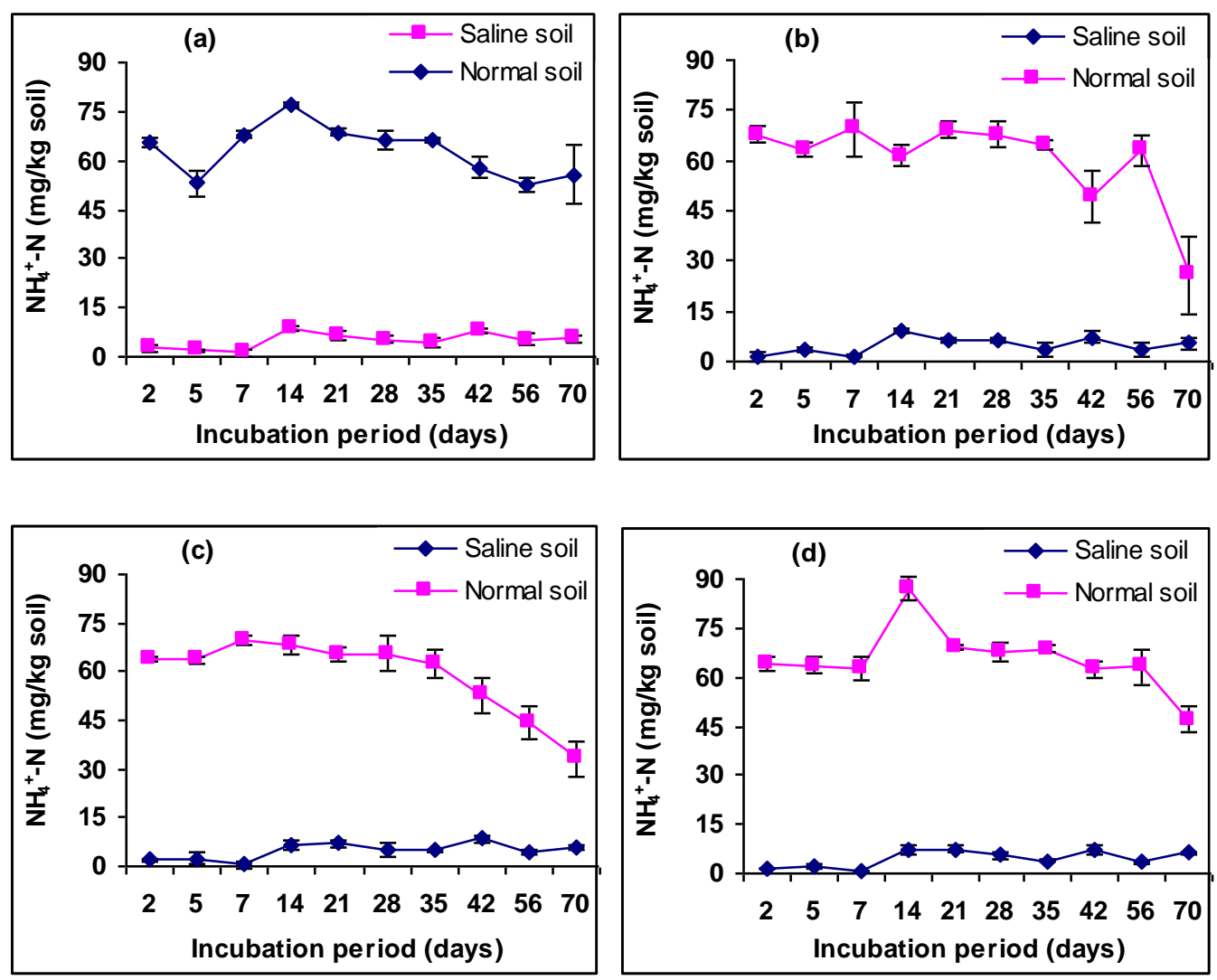

Figure 2: Release of $\mathrm{NH}_{4}{ }^{+}-\mathrm{N}$ from the non-saline and saline soil amended with poultry manure (a), goat manure (b), cow dung (c) and untreated control (d). Values given here are the means $(n=4) \pm$ standard deviation.
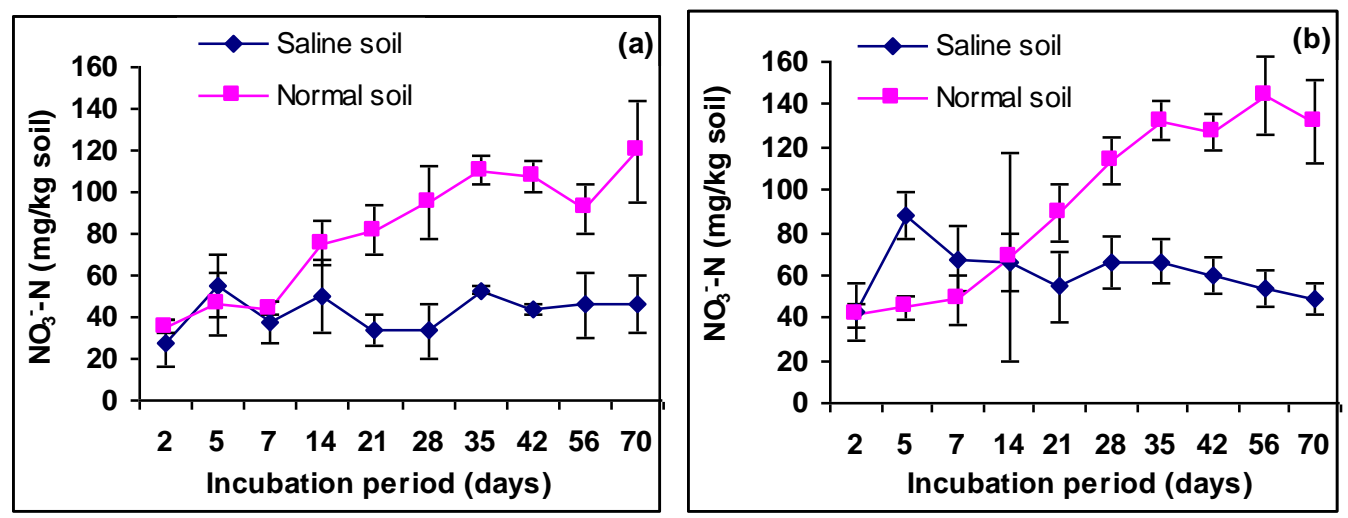

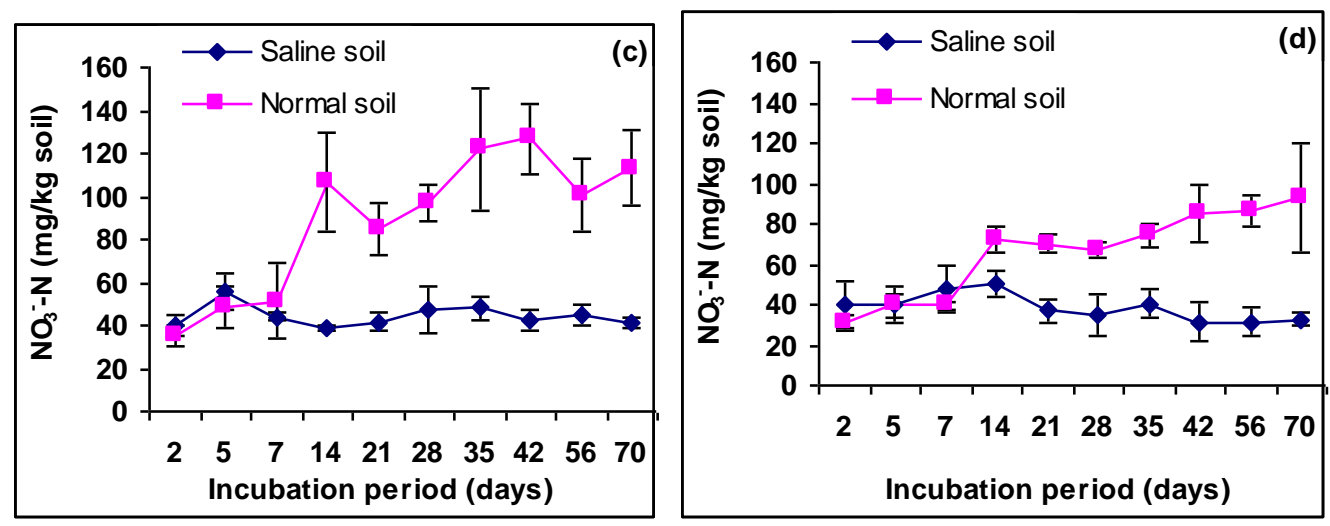

Figure. 3: Release of $\mathrm{NO}_{3}^{-}-\mathrm{N}$ from the non-saline and saline soil amended with poultry manure (a), goat manure (b), cow dung (c) and untreated control (d). Values given here are the means $(n=4) \pm$ standard deviation.

\section{CONCLUSIONS}

Salinity caused reductions in the rates of $\mathrm{CO}_{2}$ evolution by 43,24 and $6 \%$ respectively in poultry manure, goat manure and cow dung amended soils. Reductions in $\mathrm{NH}_{4}{ }^{+}-\mathrm{N}$ content was also significantly low in saline soils. Therefore it could be concluded that the response pattern of $\mathrm{C}$ and $\mathrm{N}$ mineralization to salinity stress is depending upon the type of animal manure incorporated to the soil. Further the mineralization pattern was found to be varied with the time also. However, studies under field conditions would provide better illustration as to how mineralization takes place in animal manure amended saline and non-saline soils.

\section{REFERENCES}

Anderson, J.P.E. (1982). Soil respiration. In: A.L. Page, R.H. Miller, and D.R. Keeney (eds) Methods of soil analysis, Part 2, $2^{\text {nd }}$ Edition. (Agronomy monograph no. 09) American Society of Agronomy, and Soil Science Society of America, Madison, Wis. pp: 837-871.

Anjum, R., A. Ahmed, Rahmatullah, M. Jahangir and M. Yousif (2005). Effect of soil salinity/sodicity on the growth and yield of different varieties of cotton. International Journal of Agricultural Biology, 4,pp: 606-608.

Asmalodhi, M. Arshad, F. Azam and M.H. Ssajjad (2009). Changes in mineral and mineralizable $\mathrm{N}$ of soil incubated at varying salinity, moisture and temperature regimes. Pakistan Journal of Botany, 41(2),pp: 967-980.

Bremner, J.M. and C.S. Mulvaney (1982). Total nitrogen. In. A.L. Page (ed.) Methods of Soil Analysis. Part 2. Chemical and Microbiological Methods. $2^{\text {nd }}$ Edition. American Society of Agronomy, pp: 1149-1178.

Calderon, F.J., G.W. McCarty, J.A. Van Kassel and J.B. Reeves (2004). Carbon and nitrogen dynamic during incubation of manured soil. Soil Science Society of America Journal, 68,pp: 1592-1599. 
Chao, W.L., K.D. Gan and C.C. Chao (1993). Nitrification and nitrifying potential of tropical and subtropical soils. Biology and Fertility of Soils, pp:15: 87-90.

Eneji, A.E., T. Honna, S. Yamamoto, T. Saitr and T. Masuda (2002). Nitrogen transformation in four Japanese soils following manure + urea amendment. Communication in Soil Science and Plant Analysis, 33,PP: 53-66.

Garcia, C., (2000). Microbial activity in soils of SE Spain exposed to degradation and desertification processes. Strategies for their rehabilitation. In: C. Garcia and M.T. Hernandez (eds.), Research and Perspectives of Soil Enzymology in Spain, CEBASCSIC, Spain, pp: 93-143.

Hadas, A. and R. Portnoy (1994). Nitrogen and carbon mineralization rates of composted manures incubated in soil. Journal of Environmental Quality, 23,pp: 1184-1189.

Mafongoya, P.L., P. Barak and J.D. Reed (2000). Carbon, nitrogen and phosphorus mineralization of tree leaves and manure. Biology and Fertility of Soils, 30(4),pp:298305.

Maithani, K., A. Arunachalam, R.S. Tripathi and H.N Pandey (1998). Influence of leaf litter quality on $\mathrm{N}$ mineralization in soils of subtropical humid forest re-growths. Biology and Fertility of Soils, 27,pp: 44-50.

Mapa, R.B., S. Somssiri and S. Nagarajah (1999). Soils of the wet zone of Sri Lanka. Soil Science Society of Sri Lanka, pp. 23-92.

Meyer, R.L., T. Kjaer and N.P. Revsbch (2002). Nitrification and denitrification near a soilmanure interface studied with a nitrate-nitrite biosensor. Soil Science Society of America Journal, 66,pp: 498-506.

Muhammad, S., T. Müller and R. G. Joergensen (2005). Relationships between soil biological and other soil properties in saline and alkaline arable soils from the Pakistani Punjab. In. Muhammad, S. Microbial use of organic substrates and maize growth, especially in saline and alkaline soils of the Pakistani Punjab. PhD thesis, Department of Soil Biology and Plant Nutrition, Faculty of Organic Agricultural Sciences, University of Kassel. pp:48-71

Nakhone, L.N. and M.A. Tabatabai, (2008). Nitrogen mineralization of leguminous crops in soils. Journal of Plant Nutrition and Soil Science, 171,pp: 231-241.

Nielsen, T.H. and NP Revsbech (1998). Nitrification, denitrification and N-liberation associated with two types or organic hot-spots in soil. Soil Biology and Biochemistry, 30,pp: 611-619.

Nourbakhsh, F. and R.P. Dick (2005). Net nitrogen mineralization or immobilization potential in a residue amended calcareous soils. Arid Land Research and Management, 19(4),pp:299-306.

Nourbakhsh, F. and A.R. Hossein (2006). Plant residue quality influences the response of N mineralization to salinity. Archive of Agronomy of Soil Science, 52: 571-577.

Pankhurst, C. E., S. Yu B. G. Hawke and B. D. Harch (2001) Capacity of fatty acid profiles and substrate utilization patters to describe differences in soil microbial communities associated with increased salinity or alkalinity at three locations in South Australia. Biology and Fertility of Soils 33,pp:204-217

Pathak, H. and D.L.N. Rao (1998). Carbon and nitrogen mineralization from added organic matter in saline and alkali soils. Soil Biology and Biochemistry, 30(6):695-702.

Qadir, M. and J.D. Oster (2002). Vegetative bioremediation of calcareous sodic soils: history, mechanisms and evaluation. Irrigation Science, 6,pp: 1-18.

Rietz, D.N. and R.J. Haynes (2003). Effects of irrigation-induced salinity and sodicity on soil microbial activity. Soil Biology and Biochemistry, 35,pp: 845-854. 
Rowell, D.M., C.E. Prescott and C.M. Preston (2001). Decomposition and nitrogen mineralization from bio-solids and other organic materials: Relationship with initial chemistry. Journal of Environmental Quality, 30,pp: 1401-1410.

Sardinha, M., T. Muller, H. Schmeisky and R.G. Joergensen (2003). Microbial performance in soils along a salinity gradient under acidic conditions. Applied Soil Ecology, 23,pp:237-244.

Sarig, S., E.B. Ruberson and M.K. Firestone (1993). Microbial activity-soil structure: response to saline water irrigation. Soil Biology and Biochemistry, 6: 693-697.

SAS Institute (1988). SAS/STAT user's guide, Release 6.03. SAS Institute, Cary, North Carolina, USA.

Searle, P.L., (1984). The Berthelot or indophenol reaction and its use in the analytical chemistry of nitrogen: a review, Analyst, 109,pp: 549-568.

Thuriès, L., M. Pansu, M.C. Larré-Larrouy and C. Feller (2002). Biochemical composition and mineralization kinetics of organic inputs in a sandy soil. Soil Biology and Biochemistry, 34(2),pp:239-250.

Vanessa, N.L., Wong, S.B. Richard Greene, B. Murphy and R. Dala (2004). The effects of salinity and sodicity on soil carbon turnover. SuperSoil 2004: $3^{\text {rd }}$ Australian New Zealand Soils Conference, 5 - 9 December 2004, University of Sydney, Australia.

Yassin, A. (2005). Adverse effects of salinity on citrus. International Journal of Agricultural Biology, 4,pp: 668-680

Yousif, A.M. and M.A. Abdalla (2009). Variations in nitrogen mineralization from different manures in semi-arid tropics of Sudan with reference to salt-affected soils. International Journal of Agricultural Biology, 11,pp: 515-520. 